\title{
Magnitude and trends of marine fish curio imports to the USA
}

\author{
Melissa Grey, Anne-Marie Blais and Amanda C.J. Vincent
}

\begin{abstract}
The curio trade in marine fishes has not previously been quantitatively analysed. As a contribution towards understanding the scale and conservation impact of such trade we summarize import and export data from the United States Fish and Wildlife Service for 1997-2001. At least 32 fish species were involved in the USA's international trade in curios, of which 24 were included on the 2004 IUCN Red List of Threatened Species, with categorizations ranging from Endangered to Data Deficient. The USA apparently imported an annual total of approximately one million fish and 360 tonnes of fish parts, worth more than USD 1.7 million, although total volume declined over the 5 years of data.
\end{abstract}

Fish curios imported to the USA reportedly came primarily from Taiwan and the Philippines, with $95 \%$ of curios obtained from wild populations. The three marine fish groups most traded for curios were sharks, seahorses and porcupinefishes. The value per individual fish fluctuated across years, with a considerable increase in the value of dried seahorses from 1997 to 2001 . The trade probably adds to conservation concerns for at least some species.

Keywords International trade, Philippines, porcupinefish, seahorses, sharks, souvenirs, Taiwan, USA.

\section{Introduction}

Marine animals are sold worldwide as curiosities (curios) and souvenirs, in both raw and processed form, but such consumption remains largely undocumented (Wood \& Wells, 1988, 1991, 1995). The large array of marine curios includes a vast number of trinkets, jewellery, art, crafts, trophies and ornaments featuring dried or preserved marine species. A marine curio could therefore be defined as the decorative or non-utilitarian use of a dead marine animal or plant, in whole or in part. Such a definition does not include marine fauna or flora consumed for food, medicines or aquarium display.

Globally the marine curio trade encompasses c. 5,000 species of molluscs (bivalves and gastropods), 40 species of corals, and unknown numbers of sponges, echinoderms (sea dollars, sea urchins and sea stars) and fish taxa (sharks, seahorses and pufferfishes) (Abbott, 1980; Wood \& Wells, 1988). Mollusc shells and corals constitute the majority of the marine curio trade in the number of species and volume traded, with thousands of tonnes sold annually (Wood \& Wells, 1988, 1995). Approximately 1,000 species of molluscs appear in the Philippines trade alone (Wood \& Wells, 1995).

\footnotetext{
Melissa Grey, Anne-Marie Blais and Amanda C.J. Vincent (Corresponding author) Project Seahorse, Fisheries Centre, University of British Columbia, 2204 Main Mall, Vancouver, British Columbia, V6T 1 Z4 Canada. E-mail a.vincent@fisheries.ubc.ca
}

Received 17 May 2004. Revision requested 9 September 2004. Accepted 17 December 2004.
Most species traded as curios are tropical in origin, primarily extracted from coral reefs (Wood \& Wells, 1995), presumably because of the aesthetic appeal of these animals. The Philippines, Singapore, Taiwan and Indonesia are, for example, major exporters of ornamental shells (Wood \& Wells, 1988). Marine curios may be sourced in bycatch from trawlers or other non-selective fishing gear, as by-products of food fisheries, from targeted fisheries, or from strandings ashore. These curios are then sold worldwide through the Internet, at beach resorts, through tourist outlets, and in urban craft, novelty and jewellery shops.

The curio trade may be economically important, with global exploitation of black corals for jewellery alone valued at 500 million USD per year (Green \& Hendry, 1999). Locally, targeted fisheries for species used as curios and manufacture of certain marine curios, particularly shellcraft, can provide employment and income in subsistence fishing communities, as in the Philippines (Salamanca \& Pajaro, 1996).

No quantitative studies have yet focused solely on the marine curio trade or its conservation impacts. For example, studies on international trades in seahorses and sharks have focused on their primary uses as traditional medicines and foods respectively, without quantifying their oft-cited consumption as marine curios (Rose, 1996; Vincent, 1996; Clarke, 2004; McPherson \& Vincent, 2004). One problem is that available national Customs statistics seldom identify the intended form of consumption, although enough data are available to suggest that the volume of sharks used in traditional medicine and curios 
has fluctuated (Rose, 1996). The three sharks currently listed on CITES Appendix II are known to have value in the curio trade (CITES, 2004). The purpose of this paper is to review existing data on curio imports of marine fishes into the USA, as revealed by official statistics, and draw inferences about possible areas of concern. We regard such work as a preliminary step towards documenting contributions of curio trades to conservation pressure on marine species. We focus on the USA because its major role as importer of marine invertebrates for curio use (Wood \& Wells, 1995) suggests that it may also import substantial numbers of marine fishes for such trinkets and souvenirs. Moreover, its estimated 1,000 curio importers and wholesalers nationally $(5,000-10,000$ retail outlets for marine curios in Florida alone) hint at a significant import capacity for such products (Abbott, 1980).

In this study we investigate (1) taxa of marine fish imported for curio use in the USA, (2) the volume and value of such trades, and (3) the declared sources of such imports. Where data allow, we undertake separate examinations for particular fish taxa with respect to their uses, volume traded, import value and provenance.

\section{Methods}

We obtained our trade data from the Office of Law Enforcement of the United States Fish and Wildlife Service (USFWS) under the Freedom of Information Act. Traders are required by regulations in 50 CFR 14.6114.64 to file a declaration for imports or exports of fish or wildlife. Failure to file such a declaration when required is a violation of the Endangered Species Act of 1973 as amended (16 U.S.C. 1531 et seq.). Customs records with data specific enough for a full analysis of the species, numbers and countries involved in the curio trade are only available through requests to the USFWS under the Freedom of Information Act.

Traders declare imports and exports of fish and wildlife products through completion of USFWS Form Number 3-177 (declaration for importation or exportation of fish or wildlife). This form ensures a minimum of consistency by providing a list of codes for traders to select each time they file information. Traders must report the species name (common and Latin names), declared value of the trade, use of the product traded, quantity traded, unit of measurement, country where the animals originated, import or export country, source of the animal, shipping date, nature of the trade (import or export), port of clearance, and the name of the importer and exporter. The validity and utility of these data depend, of course, on the accuracy of the declared information.

Because the USFWS retains trade records for 5 years, we were able to obtain data for 1997-2001 for the 11 (of
Table 1 List and description of potential codes (see text for details) for which data were requested from the USFWS because they may include marine fish curios.

\begin{tabular}{ll}
\hline Curio Code & Description \\
\hline BOC & Bone product or carving \\
BOD & Dead animal (whole animal) \\
BON & Bones (including jaws, but not skulls) \\
BOP & Bone pieces (not manufactured) \\
JWL & Jewellery (other than ivory) \\
SHE & Shells (molluscs, raw or unworked) \\
SKE & Skeletons \\
SKU & Skulls \\
SPR & Shell products (mollusc or turtle) \\
TEE & Teeth \\
TRO & Trophies (all trophy parts of one animal, \\
& if they are exported together) \\
\hline
\end{tabular}

78) description codes that could have applied to the use of fish as curios (Table 1). From preliminary analyses of the USFWS database, we found that some description codes, such as SHE and SPR, were used for fish parts, especially for sharks and seahorses. To eliminate fish consumed in other ways (e.g. aquarium display, pharmaceuticals and traditional medicines), we only retained import records for companies that we confirmed (through Internet searches) to deal in curios, including taxidermy. Data for imports by individuals were also retained for our analyses. Percentages are either of the total volume for all marine curio imports or of the specific taxon under analysis, according to the context. All data on values refer to declared import value.

We were able to differentiate between the two main uses for dried seahorses, because both traditional medicines and curios were listed under the import codes that we requested (Table 1), and could be disentangled through examination of the importing companies. Such analysis was impossible for sharks and other taxa at this time, because their other uses (e.g. for food or aquarium display) were not included in the 11 curio codes for which we acquired data.

USFWS data reported imports of seahorses and sharks by both weight and number of individuals. For seahorses we used a ratio of 300 seahorses $\mathrm{kg}^{-1}$ to convert weights into number of individuals (Vincent, 1996). The absence of such estimates for sharks forced us to retain the two sets of data and to report both import numbers and weights for sharks; these should be considered additive.

\section{Results}

We focus on imports for the remainder of the paper, as they constituted $97 \%$ of the total records for fish. Most exports (constituting 3\% of the total fish records) were destined for Canada and comprised undefined fish species, shark species and marine game and 
tropical fish species. An average of 55,579 \pm SD 119,882 individual fish and parts were reportedly exported each year, with a mean value of USD 87,574 \pm SD 183,524.

\section{All taxa}

USFWS data reported trade in at least 28 species of marine fishes for curios: 15 species of sharks, seven species of marine tropical, and six species of marine temperate fish (Table 2). The data also referred to four more genera, two sharks and two tropical fishes, that would have included at least one species each, and possibly more (Table 2). At least 63 companies imported curios in the USA during the reporting period, as did many individuals $(n=280)$. Most marine fishes were imported as trophies $(43 \%)$, but other products included jewellery $(20 \%)$, teeth $(19 \%)$, whole animals $(10 \%)$ and bones $(8 \%)$.

Over 1997-2001 an annual average of 360,177 \pm SD $180,088 \mathrm{~kg}$ and $1,008,909 \pm \mathrm{SD} 737,831$ fish parts and individuals, respectively, were reportedly imported to the USA. The overall weight showed no noticeable trend, while the total number of fish imports declined over the reporting period (Fig. 1). The declared annual import value of fish curios totalled USD 1.7 million \pm SD $1,674,117$, with no apparent trend over the 5 years (Fig. 2). The 1999 peak in import value (>USD 4.6 million) resulted from imports under the general category of 'fish'. We infer that these were marine game fish, based on their high value, description code (TRO) and import by taxidermy companies.

Table 2 Fish taxa traded as curios, their primary declared country of consignment and \% of the total documented curio trade for the species from that country, and Red List status (IUCN, 2004). References are provided for species whose distribution does not include the country cited as the primary source of consignments.

\begin{tabular}{|c|c|c|c|c|}
\hline Species & Common name & Declared source & $\%$ of total trade & Red List status ${ }^{1}$ \\
\hline \multicolumn{5}{|l|}{ Sharks } \\
\hline Alopias vulpinus & Thresher & India & 95 & DD; NT in California \\
\hline Carcharhinus amblyrhynchos & Gray reef & Taiwan & 91 & $\mathrm{LR} / \mathrm{nt}$ \\
\hline Carcharhinus leucas & Bull & Taiwan & 82 & $\mathrm{LR} / \mathrm{nt}$ \\
\hline Carcharhinus melanopterus & Black-tip reef & Guyana² $^{2}$ & 93 & $\mathrm{LR} / \mathrm{nt}$ \\
\hline Carcharodon carcharias & White & Taiwan & 60 & VU \\
\hline Chlamydoselachus anguineus & Frilled & New Zealand & 100 & NT \\
\hline Galeocerdo cuvier & Tiger & Taiwan & 49 & $\mathrm{LR} / \mathrm{nt}$ \\
\hline Isurus oxyrinchus & Shortfin mako & Taiwan & 85 & $\mathrm{LR} / \mathrm{nt}$ \\
\hline Lamna nasus & Porbeagle & Taiwan $^{2}$ & 90 & $\mathrm{LR} / \mathrm{nt}$; VU in NE Atlantic \\
\hline Odontaspis noronhai & Bigeye sand tiger & Taiwan $^{2}$ & 55 & DD \\
\hline Prionace glauca & Blue & Taiwan & 65 & $\mathrm{LR} / \mathrm{nt}$ \\
\hline Pristis spp. & Sawfish & Indonesia & 85 & Some spp. EN, some CR \\
\hline Rhincodon typus & Whale & India & 100 & VU \\
\hline Rhynchobatus djiddensis & Giant guitarfish & India & 100 & VU \\
\hline Somniosus antarcticus & Southern sleeper & New Zealand & 100 & DD \\
\hline Sphyrna spp. & $\begin{array}{l}\text { Hammerhead, } \\
\text { Winghead, } \\
\text { Bonnethead }\end{array}$ & Taiwan & 68 & $\begin{array}{l}\text { Some spp. LR/nt, } \\
\text { some NT, some DD }\end{array}$ \\
\hline Squatina squatina & Angel & Taiwan $^{2}$ & 72 & VU \\
\hline \multicolumn{5}{|l|}{ Tropical fishes, including seahorses } \\
\hline Hippocampus hippocampus & Short-snouted seahorse & Philippines $^{3}$ & 75 & DD \\
\hline Hippocampus histrix & Thorny seahorse & Philippines & 100 & DD \\
\hline Hippocampus kuda & Yellow/Spotted seahorse & Philippines & 97 & VU \\
\hline Hippocampus zosterae & Dwarf seahorse & Philippines $^{3}$ & 60 & DD \\
\hline $\begin{array}{l}\text { Hippocampus angustus } \\
\text { (syn. H. erinaceus) }\end{array}$ & Narrow-bellied seahorse & Philippines $^{3}$ & 100 & DD \\
\hline Balistoides viridescens & Titan triggerfish & Philippines & 100 & Not listed \\
\hline Diodon histrix and D. spp. & Porcupinefish spp. & Philippines & 99 & Not listed \\
\hline Tetraodon spp. & Pufferfish spp. & Philippines & 95 & Not listed \\
\hline \multicolumn{5}{|c|}{ Marine/anadromous game \& temperate fishes } \\
\hline Acipenser transmontanu; A. fulvescens & Sturgeon spp. & Canada & 52 & $\mathrm{LR} / \mathrm{nt} ; \mathrm{VU}$ \\
\hline Oncorhynchus tshawytscha, O. nerka & Salmon spp. & Canada & 97 & Not listed \\
\hline Salvelinus fontinalis & Brook charr & Canada & 98 & Not listed \\
\hline Xiphias gladius & Swordfish & Taiwan & 100 & DD \\
\hline
\end{tabular}

${ }^{1} \mathrm{CR}$, Critically Endangered; EN, Endangered; VU, Vulnerable; LR/nt, Lower Risk/near threatened (IUCN, 1994); NT, near threatened (IUCN, 2001); DD, Data Deficient

${ }^{2} \mathrm{IUCN}, 2004$

${ }^{3}$ Lourie et al., 1999 


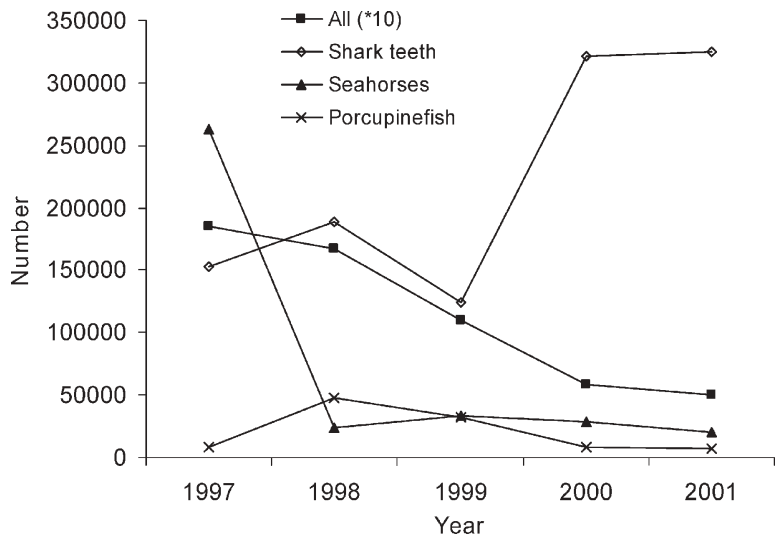

Fig. 1 Number of all fish and primary fish taxa imported into the USA during 1997-2001. Note that values for 'All' have been divided by 10. (Source USFWS).

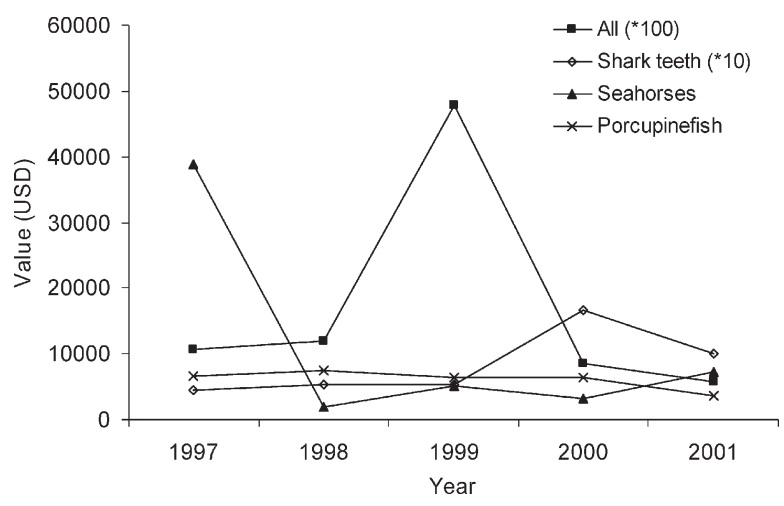

Fig. 2 Declared import values of all fish and primary fish taxa imported into the USA during 1997-2001. Note that values for 'All' have been divided by 100 and values for 'Shark teeth' have been divided by 10. (Source USFWS).

Marine fish curios were reportedly sourced from a total of 21 countries, with high proportions coming from Taiwan (45\%), the Philippines (27\%), and Mexico and Canada ( $5 \%$ each). Imports from Taiwan were primarily sharks, those from the Philippines and Mexico comprised mainly seahorses, and those from Canada were mostly marine game fish, principally salmon and charr. More than $50 \%$ of the records from Canada were coded as either trophies or bodies (TRO or BOD; Table 1) and were imported by taxidermy companies.

Nearly $95 \%$ of all specimens in the USFWS data reportedly came from the wild, while the rest of the entries were captive bred or listed as 'undefined fish species'.

\section{Sharks (Class Chondrichthyes)}

Sharks constituted the most important single identifiable taxon of fish in terms of value and volume of imports. At least 17 shark species were reportedly imported to the US over 1997-2001 (Table 2). Shark products from shortfin mako Isurus oxyrinchus, tiger Galeocerdo cuvier, and from various species of Sphyrna (including the common hammerhead Sphyrna zygaena) dominated imports, constituting 24, 17 and $9 \%$ of the value respectively. Most shark curios were imported as teeth $(66 \%)$ or worked jewellery (24\%), although $10 \%$ was imported as bone pieces, jaws, skulls, trophies, shell products, and bone products or carvings.

We cannot calculate the total number of sharks in the curio trade each year because most imports consisted only of shark parts (i.e. teeth and bone). However, the purported mean weight of shark imports was 29,051 \pm SD $21,541 \mathrm{~kg}$. The value of all shark curio imports was USD 132,140 \pm SD 46,041 each year over 1997-2001. The USA also reportedly imported an average of $222,484 \pm$ SD 94,780 shark teeth per annum, worth an average of USD 83,357 \pm SD 51,209 per annum (Figs 1 \& 2 , respectively). One tooth had an average reported value of USD $0.37 \pm$ SD 0.105 , with no evident trend in value per shark tooth over 1997-2001 (Fig. 3). Reportedly, shark curios were sourced from Taiwan (92\%), India $(5 \%)$, and Indonesia (3\%). USFWS records showed that nearly $98 \%$ of all shark curios came from wild-caught animals, and the remaining $2 \%$ were listed as coming from captive bred sharks or from undefined sources.

\section{Seahorses (Hippocampus spp., family Syngnathidae)}

Seahorses were the second most important identifiable taxon in terms of value and volumes of imports. USFWS data showed at least five seahorse species, but no other syngnathids, were imported for curios during 1997-2001. The majority (75.5\%) were merely listed as Hippocampus spp. but records also referred specifically to Hippocampus histrix (probably H. barbouri, S. Lourie, pers. comm.; $12.2 \%), H$. hippocampus (8\%), H. kuda (3\%), H. erinaceus (probably $H$. angustus, S. Lourie, pers. comm.; 1\%), and

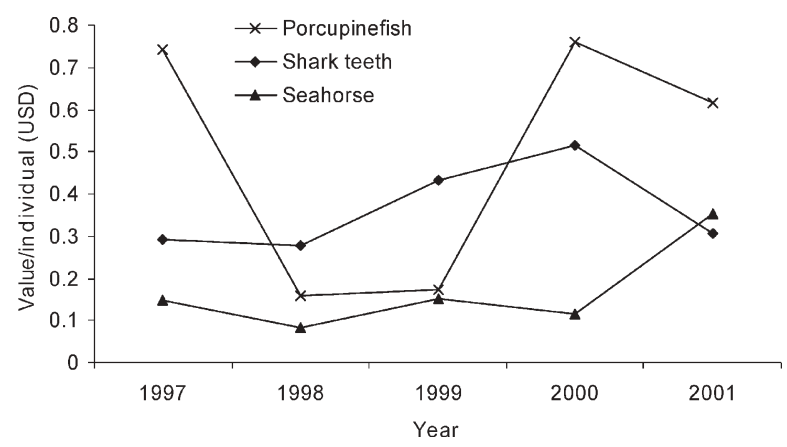

Fig. 3 Import values (USD) per individual (number of whole animals or teeth) for imports to the USA of porcupinefish, shark teeth and seahorses during 1997-2001. (Source USFWS). 
H. zosterae $(0.3 \%)$. Given their declared sourcing in the Philippines, the names $H$. hippocampus and $H$. zosterae (at least) must be incorrect, with the former limited to the Eastern Atlantic and Mediterranean and the latter found only in the Gulf of Mexico and the Bahamas (Lourie et al., 1999).

Although seahorses are also traded for traditional medicines and aquarium display, their use as curios could be deduced from the importing company listed in the USFWS database. Seahorse curios reportedly included whole bodies (93\%), shell products $(5 \%)$, jewellery $(1.5 \%)$ and skeletons $(0.5 \%)$. It appears that the curio trade consumed c. $33 \%$ of dried seahorses reportedly imported to the USA for commercial purposes (not destined for scientific/educational institutions), with the rest going to traditional medicines.

A mean of $64,738 \pm$ SD 97,398 individual seahorses, across all species, was reportedly imported for curios each year (Fig. 1), with an average value of USD $9,807 \pm$ SD 14,321 (Fig. 2). The price per individual seahorse averaged USD $0.16 \pm$ SD 0.095 but increased noticeably over the reporting period ( Fig. 3). Seahorses were claimed to come from the Philippines (61\%), Mexico (29\%), and India and New Zealand (5\% each). USFWS records showed that nearly $99 \%$ of all seahorses traded as curios were wild-caught, and the remaining $1 \%$ was listed as coming from undefined sources.

\section{Porcupinefish (Diodon, family Diontidae)}

The third most important taxon imported for marine curios was the porcupinefishes. They were often sold desiccated, inflated, and lacquered as parts of shell arrangements or as hanging lampshades. Approximately $13 \%$ of the import records for porcupinefishes referred to Diodon histrix, while the rest cited only Diodon spp. Whole bodies (85\%), shell products $(10 \%)$, and shells (5\%) comprised the documented trade in porcupinefish. The USA reportedly imported an average of 20,267 \pm SD 18,766 porcupinefish per annum (Fig. 2), totalling USD $5,743 \pm$ SD 1,802 each year over 1997-2001. The value per individual porcupinefish showed no apparent trend over the reporting period (Fig. 3), with an average cost of approximately USD $0.48 \pm$ SD 0.288 each year. Porcupinefish were reportedly sourced from the Philippines (95\%), Mexico (4\%) and Thailand (1\%), with $98 \%$ wild caught and the other $2 \%$ from undefined sources.

\section{Discussion}

The USA annually imported more than a million fish products for use as curios, at a scale that should prompt further assessment of its potential impacts. The low value of curio imports, especially when compared to other luxury use of fishes, may explain why such trade has received little attention to date. Imports of marine aquarium fishes are, for example, worth millions of dollars annually (Adams et al., 2000). The sourcing of cheap imported marine trinkets and crafts in tropical and/or developing countries, such as Mexico and the Philippines, may also explain the lack of attention to the potential impacts of such exploitation. The most obviously low-volume, high-value trophy market in marine curios appears to arise primarily from Canada, with its putatively greater management capacity. The impact of the marine curio trade needs to be assessed, especially as most fish imported to the USA reportedly came from the wild, even for species of conservation concern (IUCN, 2004).

Although large, the total volume and value of the USA's marine fish curio imports were substantially smaller than similar curio imports for marine invertebrates. The USA's imports of unprocessed ornamental shells remains large, despite dropping from 1,000-2,000 tonnes per year to only c. 1,000 tonnes annually since 1983 (Wood \& Wells, 1995). In 1986, the most recent year for which we could find an estimate, the USA's imports of shellcraft (ornamental shells processed prior to export) were worth more than USD 10 million, primarily sourced from the Philippines (Wood \& Wells, 1995), compared to the USD 1.7 million value we calculated for imports of fish curios.

Given its domestic trade, the USA's total consumption of marine fish in curios may be considerably greater than the USFWS data reveal. Florida probably plays a major role in the USA's domestic curio trade, given its many curio shops (Abbott, 1980), large volume and value of marine life extracted for the aquarium and curio trades, and its nearly two-fold increase in the number of licensed collectors for these trades over 1990-1997 (Adams et al., 2001). The total dockside value of landings for marine ornamentals in Florida was USD 1.9 million in 1998 and the number of licensed collectors increased from 66 to 114 over 1990-1997 (Adams et al., 2001). Further research or more detailed record keeping will help to distinguish between the use of such landings for aquarium display and curios.

The many gaps and inconsistencies in the USFWS data (as in many formal trade records; see Rose, 1996, and Vincent, 1996 for examples) mean that our assessments of the marine fish curio trade are certainly flawed. For example, our insistence on using only data where the company clearly dealt in curios meant that we set aside about $35 \%$ of the entries in the database, thus potentially underestimating trade. We also faced other data problems that precluded use of some entries. In one instance, we dismissed the records for seahorse teeth (at a value of USD 8,278), as seahorses have none; the African source and the description codes of TEE (teeth), TRO (trophy), 
or IVC (ivory carving) hint that these entries may rightly be for hippopotamus teeth, which fetch high prices. We did, however, retain other erratic data, having no good biological or economic basis for dispensing with outliers or evaluating the realism of apparent large scale change. Given our intention to document the overall scale of trade in each taxon, we also retained the records where the declared species identification was not appropriate for the declared source country, while flagging these concerns in the paper.

For all its flaws, the USFWS data set provides rare quantitative documentation of curio trades, and should help estimate bounds on the trade and direct further research on the scale and impact of such exploitation. Subsequent studies will need to monitor wild source populations, analyse fisheries catch and effort data, and document imports and exports. Previous work on marine shells inferred that none were threatened by over-collection for curios (Wood \& Wells, 1995; Ponder \& Grayson, 1998). However, population data for most animals were scarce, knowledge of their basic biology was scant, and their role in ecosystems was poorly studied (Wood \& Wells, 1991). Moreover, collection may disrupt populations indirectly, by damaging habitats through trampling, rock removal, dredging and breakage.

We hypothesize that the decline in marine curio imports in the USA over 1997-2001 may be explained by any of (a) declines in wild populations of those animals, (b) declines in fishing effort that landed curios as bycatch, (c) difficulties in importing goods due to international restrictions, and/or (d) reduced demand for curios in the USA. It will take some time to assess these different hypotheses, but precautionary conservation action may be advisable, as half of the fish taxa reportedly imported for curios are listed as Threatened or Near Threatened on the 2004 IUCN Red List, with a further quarter of the species recorded as Data Deficient (IUCN, 2004; Table 2). In that context, we consider possible conservation considerations relating to imports of the three most commonly used taxa.

\section{Sharks}

A lack of understanding of how shark curios are obtained and a lack of population data for most shark species make it difficult to assess the effect of the curio trade per se on shark populations. It seems that most shark curios may enter trade as a by-product of food fisheries, but shark hunting for curios may also represent a target fishery, at least for those sharks whose body parts are more valuable than the meat. For example, great white sharks Carcharodon carcharias are reportedly increasingly hunted for their teeth and jaws in South Africa (Gosling, 2003). A great white shark jaw could fetch USD 10,000 and a single tooth could sell for USD 100 (Gosling, 2003).
Many sharks may be susceptible to overfishing because of slow growth, low fecundity, long maturation periods, and long reproductive cycles (Camhi et al., 1998; Castro et al., 1999). The three sharks most commonly imported to the USA as curios (shortfin mako, tiger, and hammerhead) are categorized as Lower Risk: near threatened, and thus in need of conservation support (IUCN, 2004). The shortfin mako has a relatively low reproductive capacity, and is subject to significant bycatch and targeted fisheries in some areas (IUCN, 2004). The tiger shark is a relatively fast growing and fecund species but populations have declined numerically, presumably because many are caught in target and non-target fisheries, and killed for their fins (IUCN, 2004). The smooth hammerhead is a relatively common and widespread shark, but again likely to suffer significant bycatch mortality in large-scale long-line and driftnet fisheries; fins from hammerhead sharks are prized in Asia and individuals caught as bycatch are unlikely to be released alive (IUCN, 2004).

International trade is now regulated in three species of sharks, none of them strongly represented in USA import data: the basking shark Cetorhinus maximus, the whale shark Rhincodon typus, and the great white shark. All are listed on Appendix II of CITES, with the latter being added in October 2004 because of perceived pressures from direct fishing for food, incidental catch and the curio trade (CITES, 2005).

\section{Seahorses}

Most species of seahorses are thought to be vulnerable to overfishing, with their usually low density, low fecundity, lengthy obligatory parental care, mate fidelity, low mobility, and small home ranges (Foster \& Vincent, 2004). Many species of seahorse are categorized as Vulnerable or Data Deficient, and one as Endangered (IUCN, 2004). Seahorses are traded for medicinals, aquaria and curios, with a total global trade of well over 20 million seahorses annually (Vincent, 1996). Much of the trade originates as bycatch from non-selective fishing gear (e.g. Baum et al., 2003a), although some seahorses are certainly target caught (Vincent, 1996). Fears that seahorse exploitation will prove unsustainable led to the inclusion of all seahorses on CITES Appendix II from May 2004. Such a listing controls all forms of export, but considerable effort will be needed to understand the curio trade, given current emphasis on aquarium and medicinal uses.

While the curio trade for shark products is often sourced from its parts (some of which will be by-product of food fisheries), the curio trade in seahorses consumes the whole animal. Such consumption is inferred to depend largely on animals discarded from the traditional medicine or aquarium trades, with no evidence yet of a fishery directed at curios (Vincent, 1996). Our inference 
that approximately one-third of the dried seahorse imports to the USA was destined for curio use should, however, prompt concern about the influence and sustainability of this consumption. In addition, the considerable $(139 \%)$ increase in the import value per individual dried seahorse over 1997-2001 raises questions about unmet demand. This price increase is not solely due to inflation. Assuming inflation averages $2.04 \%$ each year (International Finance Center, 2004), we would expect a price increase of only $8 \%$ during that time period. A lack of significant increases in other taxa, where we would expect similar inflationary price increases, may mean that prices for those taxa are declining slightly.

Our analysis suggests similar import volumes of seahorses for traditional medicine and for aquarium display, with both trades perhaps only twice as large as imports for curios. The USA is thought to be a significant consumer of live seahorses for the aquarium trade (Wabnitz et al., 2003), with estimates from trade surveys and fisheries monitoring in exporting countries indicating volumes of hundreds of thousands of animals each year (Vincent, 1996). The USFWS' own data for 1996 to 2003, however, indicated imports of only 31,000 animals in total (Bruckner et al. in press). Probably the USFWS data represent a gross underestimate because they were gathered prior to the CITES listing and its associated record-keeping, and most seahorses are traded with other tropical fish and coded as such by customs officials in the USA (Bruckner et al., in press). Such discrepancies should now narrow as record keeping improves in both exporting and importing nations under CITES regulations. Moreover, all exports under Appendix II, for any form of use, will have to be sustainable in order to be permissible.

\section{Porcupinefish}

Little is known about the biology of porcupinefish, and population estimates are rare. They are sought for aquarium display (Randall et al., 1990) and are especially vulnerable to by-catch (Stobutzki et al., 2001). Wood \& Wells (1991) recommended that these fish should be avoided for use as curios because of their importance in reef and kelp ecosystems, but such ecological roles appear to be poorly studied. No species are known to have been evaluated for the IUCN Red List and none have been proposed for CITES listings. To our knowledge there are no other uses for the porcupinefish than for the aquarium trade and curios.

\section{Conclusions}

Although the curio trade can add to pressures on fish exploited for curios, even at low levels of exploitation, it is not likely to be the major stress on populations of the species imported to the USA. Further evaluation of the impacts of curio trades on wild populations will need to consider the many other pressures that may be acting on these species and their ecosystems, including habitat degradation (e.g. coral reefs, Wilkinson, 2000), industrial fishing pressures (e.g. sharks, Baum et al., 2003b; seahorses, Vincent, 1996); and non-selective fishing gear (e.g. sharks, de Silva et al., 2001; seahorses, Baum et al., 2003a).

In undertaking our analysis of existing trade data, we hope to provoke greater interest in the potential value and importance of the trade for marine curios. If they can be well-managed as low-volume, high-value exploitation (as may be the case with fish trophies in Canada), then fisheries and trades in marine curios should be able to promote marine conservation. Despite campaigns to discourage purchase of marine curios (with some public aquaria, for example, eschewing such goods in their shops; C. Mell, pers. comm.) there is no inherent reason why luxury trades such as curios should be discouraged if their viability and sustainability can be ensured through wise regulation and management.

Future work should incorporate both biological and economic analysis of sustainability. More accurate trade declarations and ongoing analysis of more USFWS trade records (for curios and other uses of the same species) should allow identification of focal research populations of possible concern. Databases on the aquarium trade (e.g. Global Marine Aquarium Database, 2005) and on particular species in trade (such as those regulated by the European Union or CITES), can be mined to advance understanding of competing exploitation pressures on curio species. Ecological assessments, such as ReefBase (2005), can help identify other pressures on the focal populations. Thereafter, research and stakeholder consultation will need to identify key life history parameters of the exploited population or species, document the manner in which the fish are removed for curios and other uses, and evaluate the relative ecological impact and economic value of different consumption. Incorporation of data sets and supplementing existing knowledge into decision analyses should help diagnose such management options as may be necessary to ensure sustainability of appropriate use.

\section{Acknowledgements}

This is a contribution from Project Seahorse. The research was funded by a Pew Fellowship in Marine Conservation to A.C.J. Vincent. We sincerely thank Janelle Curtis, Bob Hunt, Sara Lourie, Jean Marcus and Jana McPherson for generous input on the manuscript. The manuscript was also improved by the comments of two anonymous reviewers. 


\section{References}

Abbott, R.T. (1980) The Shell and Coral Trade in Florida. Special Report 3. TRAFFIC (USA), Washington, DC, USA.

Adams, C.M., Larkin, S.L., Degner, R.L., Lee, D.J. \& Milon, W.J. (2000) International Trade in Live, Ornamental "Fish" in the U.S. and Florida. Unpublished Report. Florida Sea Grant College Program [http:/ / www.agmarketing.ifas.ufl.edu/ downloads/mo_trade.pdf, accessed 5 May 2005].

Adams, C.M, Larkin, S.L. \& Lee, D.J. (2001) Volume and value of marine ornamentals collected in Florida, 1990-98. Aquarium Sciences and Conservation, 3, 25-36.

Anon. (in press) U.S. National Report for the International Seahorse Fishery Management Workshop. Proceedings of the International Seahorse Fishery Management Workshop, Mazatlan, Mexico. Technical Memorandum of the U.S. Dept. of Commerce. NOAA Fisheries, Silver Spring, USA.

Baum, J.K., Meeuwig, J.J. \& Vincent, A.C.J. (2003a) Bycatch of lined seahorses (Hippocampus erectus) in a Gulf of Mexico shrimp trawl fishery. Fishery Bulletin, 101, 721-731.

Baum, J.K., Myers, R.A., Kehler, D.G., Worm, B., Harley, S.J. \& Doherty, P.A. (2003b) Collapse and conservation of shark populations in the northwest Atlantic. Science, 299, 389-392.

Bruckner, A.W., Field, J.D. \& Daves, N. (eds) (in press) The Proceedings of the International Workshop on CITES Implementation for Seahorse Conservation and Trade. NOAA Technical Memorandum NMFS-OPR-36, Silver Spring, USA.

Camhi, M., Fowler, S., Musick, J., Bräutigam, A. \& Fordham, S. (1998) Sharks and Their Relatives: Ecology and Conservation. Occasional paper of the IUCN Species Survival Commission No. 20. IUCN, Gland, Switzerland.

Castro, J.I., Woodley, C.M. \& Brudek, R.L. (1999) A Preliminary Evaluation of Status of Shark Species. FAO Fisheries Technical Paper 380. FAO, Rome, Italy.

Clarke, S. (2004) Shark Product Trade in Mainland China and Hong Kong and Implementation of the CITES Shark Listings, TRAFFIC East Asia, Hong Kong, China.

CITES (2004) CITES. Proposal Document 11.48. Http:/ / www.cites.org/eng/cop/11/doc/48.pdf [accessed 10 September 2004]

CITES (2005) Convention on International Trade in Endangered Species of Wild Fauna and Flora. Http: / / www.cites.org [accessed 6 May 2005].

Foster, S.J. \& Vincent, A.C.J. (2004) Life history and ecology of seahorses: implications for conservation and management. Journal of Fish Biology, 65, 1-61.

Global Marine Aquarium Database (2005) Http:/ / www. unep-wcmc.org/marine/GMAD [accessed 6 May 2005].

Gosling, M. (2003) Great White Sharks Under Attack by Curio Pirates. Cape Times online. Http:/ / www.capetimes.co.za [accessed 14 December 2003].

Green, E.P. \& Hendry, H. (1999) Is CITES an effective tool for monitoring trade in corals? Coral Reefs, 18, 403-407.

International Finance Center (2004) North America: United States Fact Sheet. Http://sg.biz.yahoo.com/ifc/us/ [accessed 15 October 2004].

IUCN (1994) 1994 Categories and Criteria (version 2.3). IUCN, Gland, Switzerland [http://www.redlist.org/info/ categories_criteria1994.html, accessed 6 May 2005].

IUCN (2001) 2001 Categories and Criteria (version 3.1). IUCN, Gland, Switzerland [http:/ / www.redlist.org/info/ categories_criteria2001.html, accessed 6 May 2005].

IUCN (2004) 2004 IUCN Red List of Threatened Species. IUCN, Gland, Switzerland [http:/ / www.redlist.org, accessed 5 May 2005].
Lourie, S.A., Vincent, A.C.J. \& Hall, H.J. (1999) Seahorses: An Identification Guide to the World's Species and Their Conservation. Project Seahorse, London, UK.

McPherson, J.M \& Vincent, A.C.J. (2004) Assessing East African trade in seahorse species as a basis for conservation under international controls. Aquatic Conservation: Marine and Freshwater Ecosystems, 14, 521-538.

Ponder, W.F. \& Grayson, J.E. (1998) The Australian Marine Molluscs Considered to be Potentially Vulnerable to the Shell Trade. Department of Environment and Heritage, Sydney, Australia.

Randall, J.E., Allen, G.R. \& Steene, R.C. (1990) Fishes of the Great Barrier Reef and Coral Sea. University of Hawaii Press, Honolulu, USA.

ReefBase (2005) ReefBase: A Global Information System on Coral Reefs. Http: / / www.reefbase.org [accessed 6 May 2005].

Rose, D.A. (1996) An Overview of World Trade in Sharks and Other Cartilaginous Fishes. TRAFFIC International, Cambridge, UK.

Salamanca, A.M. \& Pajaro, M.G. (1996) The utilization of seashells in the Philippines. Traffic Bulletin, 16, 61-72.

de Silva, J.A., Condrey, R.E. \& Thompson, B.A. (2001) Profile of shark bycatch in the U.S. Gulf of Mexico menhaden fishery. North American Journal of Fisheries Management, 21, 111-124.

Stobutzki, I., Miller, M. \& Brewer, D. (2001) Sustainability of fishery bycatch: a process for assessing highly diverse and numerous bycatch. Environmental Conservation, 28, 167-181.

Vincent, A.C.J. (1996) The International Trade of Seahorses. TRAFFIC International, Cambridge, UK.

Wabnitz, C., Taylor, M., Green, E. \& Razak, T. (2003) From Ocean to Aquarium: The Global Trade in Marine Ornamentals. UNEP-WCMC, Cambridge, UK.

Wilkinson, C.R. (2000) Status of Coral Reefs of the World. Australian Institute of Marine Science, Townsville, Australia.

Wood, E. \& Wells, S.M. (1988) The Marine Curio Trade: Conservation Issues. Marine Conservation Society, Ross-on-Wye, UK.

Wood, E. \& Wells, S.M. (1991) The Marine Curio Trade: Conservation Guidelines and Legislation. Marine Conservation Society, Ross-on-Wye, UK

Wood, E. \& Wells, S.M. (1995) The shell trade: a case for sustainable utilization. In The Conservation Biology of Molluscs. Occasional Paper of the IUCN Species Survival Commission No. 19 (ed. E.A. Kay), pp. 41-52. IUCN, Cambridge, UK.

\section{Biographical sketches}

Melissa Grey's research in marine science is wide-ranging and includes evolutionary, palaeobiological and conservation studies. She is currently investigating modes of speciation for the extinct bivalve Buchia.

Anne-Marie Blais is a limnologist currently working as Project Manager for an environmental consulting company, dealing with impact assessment and monitoring studies of human activity on aquatic systems and fish habitats.

Amanda Vincent holds the Canada Research Chair in Marine Conservation. Her early research on seahorse ecology has led to broad initiatives in conservation science, management and policy, often featuring seahorses. She is particularly interested in the use of marine resources for non-food purposes, addressing challenges associated with data-poor subsistence fisheries, assessment of marine trades, and recognition of marine fishes as wildlife. 